\title{
EVALUATION OF YIELD AND YIELD COMPONENTS OF COMMON VETCH (VICIA SATIVA L.) GENOTYPES GROWN IN DIFFERENT LOCATIONS OF TURKEY BY GGE BIPLOT ANALYSIS
}

\author{
AYDEMIR, S. K. ${ }^{1}-$ KARAKOY, T. ${ }^{2 *}-$ KOKTEN, K. ${ }^{3}-$ NADEEM, M. A. ${ }^{4}$ \\ ${ }^{1}$ Department of Field Crops, Faculty of Agriculture and Natural Science, Seyh Edebali \\ University, Bilecik, Turkey \\ ${ }^{2}$ Faculty of Agricultural Sciences and Technologies, Sivas University of Science and \\ Technology, Sivas, Turkey \\ ${ }^{3}$ Faculty of Agriculture, Bingol University, Bingol, Turkey \\ ${ }^{4}$ Department of Field Crops, Faculty of Agricultural and Natural Science, Bolu Abant Izzet \\ Baysal University, Bolu 14030, Turkey \\ *Corresponding author \\ e-mail:tolgakarakoy73@hotmail.com \\ (Received $1^{\text {st }}$ Jul 2019; accepted $25^{\text {th }}$ Oct 2019)
}

\begin{abstract}
This study was carried out under the ecological conditions of three locations in Turkey (Bilecik, Sivas and Bingol) during 2016 aiming to investigate the variations in yield and yield components of common vetch and to evaluate in different environmental conditions the best performing genotypes using the GGE Biplot analysis. 5 lines and 8 commercial cultivars were used as plant material. GGE biplot analysis concluded that plant height, forage yield, biological yield and straw yield were included in component 1 . Dicle genotype was found superior in terms of forage yield and dry matter yield, while Kralkizi genotype reflected its potential for biological and straw yield. Findings of this study are suggesting that the common vetch, plant height, forage yield, biologic yield, straw yield are important traits and can be used as selection criteria for the evaluation of best performing common vetch genotypes.

Keywords: common vetch, Vicia sativa, genotype, yields, environment, genotype x environment interactions
\end{abstract}

\section{Introduction}

Turkey is one of the world's biodiversity centre and considered origin and domestication center for various crops, thanks to its geographic (Arystanbekkyzy et al., 2019; Nadeem et al., 2018), containing 20.5 million hectares of processed agricultural land and forage crops are cultivated on an area of 1.8 million ha (TUIK, 2013). Among the various cultivated forage crops in Turkey, common vetch is considered to be the 2nd most cultivated forage crop after clovers covering 499 thousand ha of (629 thousand ha) plantation area. However, it is observed that this increase in the area of forage crops is not sufficient to meet the demands for roughage of Turkish farm animals (Acar et al., 2015). Besides this, low average meat and milk yields and quality of animal products is low here in Turkey (Yucel et al., 2008). However, according to Gokkus and Koc (1996), field residues are not enough to meet with roughage needs for the whole country. In order to reduce feed gap and decrease fallow fields, it is necessary to increase the cultivation area of forage crops.

In order to feed our animals with high quality feed, and to prevent excessive and early grazing of meadows and pastures, the production of forage crops should be given 
great importance. Therefore, it is necessary to increase the cultivation area of forage crops, to explain the benefits and importance of these crops, to encourage cultivation, initiate breeding activities for these crops to develop new improved varieties superior in quality and yield (Ozkose and Ekiz, 2005; Ayasan, 2010).

Common vetch (Vicia sativa L.), which is one of the most important forage crops and serving a source of feed for animals all around the world, is an important species of Vicia genus containing a total of 150 species (Tosun, 1974). According to Elci and Acikgoz (1993), Turkey is rich with the flora of this genus and a total of 59 Vicia species can be found in Turkey. However, less efforts has been done for the breeding of this important forage crop and only 14 commercial cultivars have been released in Turkey. One of the most important goals in agriculture is to obtain more products or yield from the unit area. In order to achieve this, it is necessary to develop new lines or varieties with superior efficiency or to determine the performance of those developed in other regions in the region (Kokten, 2011).

Vetch plant, which can be used in both grass and grain, has a short period of vegetation, can grow in almost all types of soils and climatic conditions. Vetch grains with protein content of more than $20 \%$ are broken into animals as concentrated feed. In addition, the remaining straw from the harvested plants for grain yield is a good animal feed (Acikgoz, 2001).

Genotype $\mathrm{x}$ environment interactions (GEI) is considered one of the main area of study for the plant breeders working on for many years. A variety of methods have been developed to characterize the behaviour of varieties under different environmental conditions. Yield trials under different environments give information about the GEI when analyzed by traditional methods, while they do not give any information about the stability measurements of genotypes. Therefore, various methods have been developed to determine the performance of the genotypes under these environments. The most important of these methods is to determine the stable genotype by stability analysis (Kilic et al., 2003).

Yield is a complex trait that depends on many other features and is largely influenced by environmental factors. However, farming community demands stable varieties with higher yield, but a little fluctuation in the performance of such varieties have been also observed when they grow in various environments. Therefore information resulted by GEI can be very beneficial in the introduction of new plant varieties in plant breeding programs (Sayar et al., 2013; Kendal and Dogan, 2015).

Understanding the relationship between plant performance and environment has been an important topic for plant breeders and geneticists (Yan, 2001). Product performance is a function of genotype $(\mathrm{G})$, environment $(\mathrm{E})$ and an interaction of both, which occur when different phenotypes, different varieties or genotypes react differently to different environments. However, the main effect of environment is not related to the evaluation of varieties. Only genotypes and GEI are important and therefore environmental impacts should be removed from data and focused on genotypes and GEI (Gauch and Zobel, 1996). GGE is the contraction of genotype + GE; The GGE of a MET dataset can be displayed in a GGE pair that allows the researcher to concentrate on the part of the MET data most useful in the evaluation of varieties. Various statistical methods have been proposed to investigate the impact of GE interaction and to use the positive part of the variety development process (Flores et al., 1998). However, not all of these methods are always effective in the analysis of GEI of multi environment/years data sets in plant breeding programs (Sabaghnia et al., 2006). This procedure enables plant 
breeders to investigate the performance of genotypes under different environments and helped to evaluate the most stable genotypes as well.

The aim of this study is to evaluate the yield and yield components of common vetch genotypes in Bilecik, Sivas and Bingol ecological conditions by using GGE Biplot analysis method and to determine the performance of these common vetch genotypes in different environments.

\section{Materials and methods}

This study was conducted in three different ecological conditions of Turkey: Bilecik, Sivas and Bingol during 2016. The GPS coordinates of these locations are Bilecik: $40^{\circ}$ 0' 57.7728" and $30^{\circ} 10^{\prime}$ 52.6692", Sivas: $39^{\circ} 42^{\prime}$ 20.9592" and $37^{\circ} 1^{\prime}$ '56.1108", Bingol: $38^{\circ} 53^{\prime} 47.5620^{\prime \prime}$ and $40^{\circ} 29^{\prime} 25.9836^{\prime \prime}$. The research was established in randomized complete blocks design combined over location with three replications. In this study, locations were random factor and genotype were considered as fixed factor. During this study 5 lines named Hat-1, Hat-7, Hat-8, Hat-13, and Hat-17 developed by Bingol University Faculty of Agriculture Field Crops Department and 8 commercial cultivary mainly used in Turkey named Kralkizi, Dicle, Gorkem, Ozveren, Cumhuriyet99, Yucel, Alinoglu, and Kubilay common vetch cultivar were used as plant materials. Simultaneous field experiments were conducted at the Bingol University Faculty of Agriculture, Research and Application Department, Cumhuriyet University, Sivas Vocational High School Herbal and Animal Program Research Area and Bilecik Şeyh Edebali University Agricultural and Natural Sciences Research and Application Field in October. In the experiment, the parcel dimensions were set as 3 replications according to the randomized block trial design with a row length of $5 \mathrm{~m}$, row between $30 \mathrm{~cm}$ row and $4-5 \mathrm{~cm}$. Fertilized with $3 \mathrm{~kg} \mathrm{~N} \mathrm{da}^{-1}$ and $5 \mathrm{~kg} \mathrm{P}_{2} \mathrm{O}_{5} \mathrm{da}^{-1}$ with sowing.

The soil properties of the environments where the research was conducted are given in Table 1.

Table 1. Some physical and chemical properties of soils

\begin{tabular}{|c|c|c|c|c|c|c|c|c|c|c|c|c|c|}
\hline \multicolumn{14}{|c|}{ Environment 1 (Bilecik) } \\
\hline $\begin{array}{c}\text { Sand } \\
(\%)\end{array}$ & $\begin{array}{l}\text { Silt } \\
(\%)\end{array}$ & $\begin{array}{l}\text { Clay } \\
(\%)\end{array}$ & Structure & pH & $\begin{array}{l}\text { Salt } \\
(\%)\end{array}$ & $\begin{array}{c}\mathbf{P}_{2} \mathbf{O}_{5} \\
\left(\mathrm{kgda}^{-1}\right)\end{array}$ & $\begin{array}{c}\mathrm{K}_{2} \mathrm{O} \\
\left(\mathrm{kgda}^{-1}\right)\end{array}$ & $\begin{array}{c}\text { Org. matter } \\
(\%)\end{array}$ & $\begin{array}{c}\text { Lime } \\
(\%)\end{array}$ & $\mid \begin{array}{c}\mathbf{F e} \\
\left(\mathbf{m g k g}^{-1}\right)\end{array}$ & $\begin{array}{c}\mathbf{Z n} \\
\left(\mathbf{m g k g}^{-1}\right)\end{array}$ & $\begin{array}{c}\mathbf{M n} \\
\left(\mathrm{mgkg}^{-1}\right)\end{array}$ & $\begin{array}{c}\mathbf{C u} \\
\left(\mathrm{mgkg}^{-1}\right)\end{array}$ \\
\hline & & \multicolumn{2}{|c|}{ Sandy-loamy } & 8.11 & 0.26 & \begin{tabular}{l|l}
3.5 \\
\end{tabular} & \begin{tabular}{|l|l}
1.1 \\
\end{tabular} & \begin{tabular}{|l|}
1.5 \\
\end{tabular} & 7.3 & 7.94 & 1.79 & 6.73 & 3.83 \\
\hline \multicolumn{14}{|c|}{ Environment 2 (Sivas) } \\
\hline $\begin{array}{c}\text { Sand } \\
(\%)\end{array}$ & $\begin{array}{l}\text { Silt } \\
(\%)\end{array}$ & $\begin{array}{c}\text { Clay } \\
(\%)\end{array}$ & Structure & $\mathbf{p H}$ & $\begin{array}{l}\text { Salt } \\
(\%)\end{array}$ & \begin{tabular}{|c|}
$\mathbf{P}_{2} \mathbf{O}_{\mathbf{5}}$ \\
$\left(\mathbf{k g d a}^{-1}\right)$
\end{tabular} & \begin{tabular}{|c|}
$\mathbf{K}_{2} \mathbf{O}$ \\
$\left(\mathbf{k g d a}^{-1}\right)$
\end{tabular} & \begin{tabular}{|c|} 
Org. matter \\
$(\%)$
\end{tabular} & $\begin{array}{c}\text { Lime } \\
(\%)\end{array}$ & $\begin{array}{c}\mathbf{F e} \\
\left(\mathbf{m g k g}^{-1}\right)\end{array}$ & \begin{tabular}{|c|}
$\mathbf{Z n}$ \\
$\left(\mathbf{m g k g}^{-1}\right)$
\end{tabular} & $\begin{array}{c}\mathbf{M n} \\
\left(\mathbf{m g k g}^{-1}\right)\end{array}$ & \begin{tabular}{|c|}
$\mathbf{C u}$ \\
$\left(\mathrm{mgkg}^{-1}\right)$
\end{tabular} \\
\hline 14.6 & 48.3 & 37.1 & $\mathrm{SiCL}$ & 7.28 & 0.33 & \begin{tabular}{|l|}
3.40 \\
\end{tabular} & 93.59 & 1.7 & 19.6 & 3.99 & 0.42 & 4.68 & 1.23 \\
\hline \multicolumn{14}{|c|}{ Environment 3 (Bingol) } \\
\hline \multirow[t]{2}{*}{$\begin{array}{c}\text { Sand } \\
(\%)\end{array}$} & $\begin{array}{l}\text { Silt } \\
(\%)\end{array}$ & $\begin{array}{l}\text { Clay } \\
(\%)\end{array}$ & Structure & pH & $\begin{array}{l}\text { Salt } \\
(\%)\end{array}$ & $\begin{array}{c}\mathbf{P}_{2} \mathbf{O}_{5} \\
\left(\mathbf{k g d a}^{-1}\right)\end{array}$ & \begin{tabular}{|c|}
$\mathrm{K}_{2} \mathrm{O}$ \\
$\left(\mathrm{kgda}^{-1}\right)$
\end{tabular} & $\begin{array}{c}\text { Org. matter } \\
(\%)\end{array}$ & $\begin{array}{c}\text { Lime } \\
(\%)\end{array}$ & $\left|\begin{array}{c}\mathbf{F e} \\
\left(\mathrm{mgkg}^{-1}\right)\end{array}\right|$ & $\begin{array}{c}\mathbf{Z n} \\
\left(\mathbf{m g k g}^{-1}\right)\end{array}$ & $\left|\begin{array}{c}\mathbf{M n} \\
\left(\mathbf{m g k g}^{-1}\right)\end{array}\right|$ & \begin{tabular}{|c|}
$\mathrm{Cu}$ \\
$\left(\mathrm{mgkg}^{-1}\right)$
\end{tabular} \\
\hline & & \multicolumn{2}{|c|}{ Loamy } & 6.37 & 0.0006 & 7.9 & 24.45 & 1.26 & 0.15 & & & & \\
\hline
\end{tabular}

When Table 1 is examined, the trial area of Bilecik location is sandy, loamy, moderate alkaline (8.11) and medium salted (0.26\%). Moreover, the amount of lime $(7.3 \%)$ and the amount of organic matter $(1.5 \%)$ is moderate and the amount of phosphorus $(3.5 \mathrm{~kg}$ $\left.\mathrm{da}^{-1}\right)$ and potassium $\left(1.1 \mathrm{~kg} \mathrm{da}^{-1}\right)$ is low and the micro element content is sufficient. The soil of the trial site of the Sivas location is low phosphorus $\left(3.4 \mathrm{~kg} \mathrm{da}^{-1}\right)$, slightly 
alkaline (7.28), low in organic matter content (1.7\%), salty (19.6\%) and silty (19.6\%). The contents of potassium $\left(\mathrm{K}_{2} \mathrm{O}\right)$ are high $\left(93.59 \mathrm{~kg} \mathrm{da}^{-1}\right)$, micro element contents are generally sufficient. The soil of the trial area of Bingol location is slightly acidic (6.37) without salt $(0.0006 \%)$, organic matter is less $(1.26 \%)$, less calcareous, potassium is less $\left(24.45 \mathrm{~kg} \mathrm{da}^{-1}\right)$ phosphorus medium $\left(7.9 \mathrm{~kg} \mathrm{da}^{-1}\right)$ level is seen.

The climate data of the environments in which the experiment was conducted are given in Figures 1, 2 and 3. When the figures are analyzed, it is seen that the average temperature, total precipitation and relative humidity are quite different from each other.

When the sub-fruits of the plants began to mature (about 120-150 days after sowing), the morphological and phenological observations of the plant were taken and the half of the parcel was cut to calculate the green grass yield (according to the Technical Instructions established on the basis of UPOV criteria of the Seed Registration and Certification Directorate). During the harvesting of green grass, $500 \mathrm{~g}$ samples of each parcel were taken and dried in a drying oven at $70{ }^{\circ} \mathrm{C}$ for $48 \mathrm{~h}$ at a constant weight and weighed and dry matter weight was calculated.

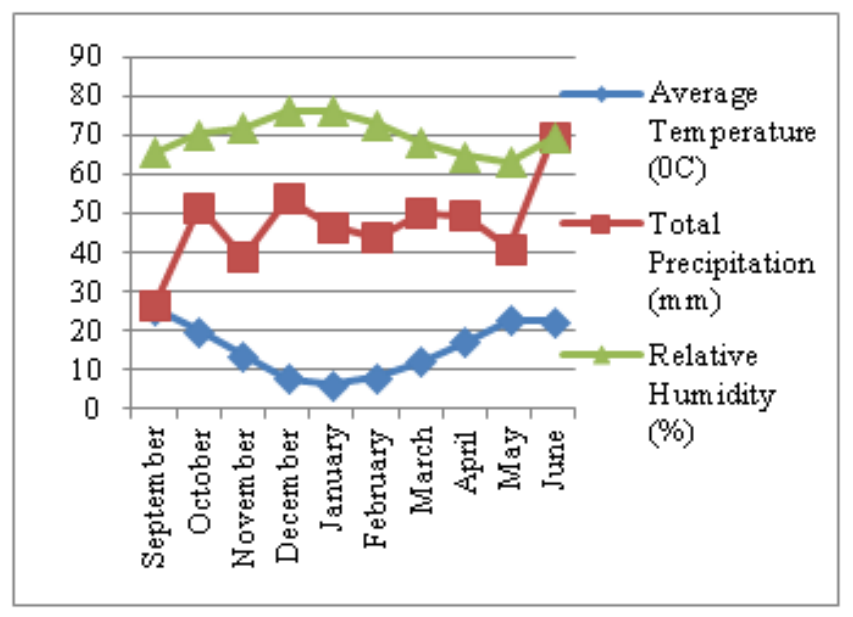

Figure 1. Climate data of 2016-17 period for the first environment (Bilecik) where the experiment was conducted

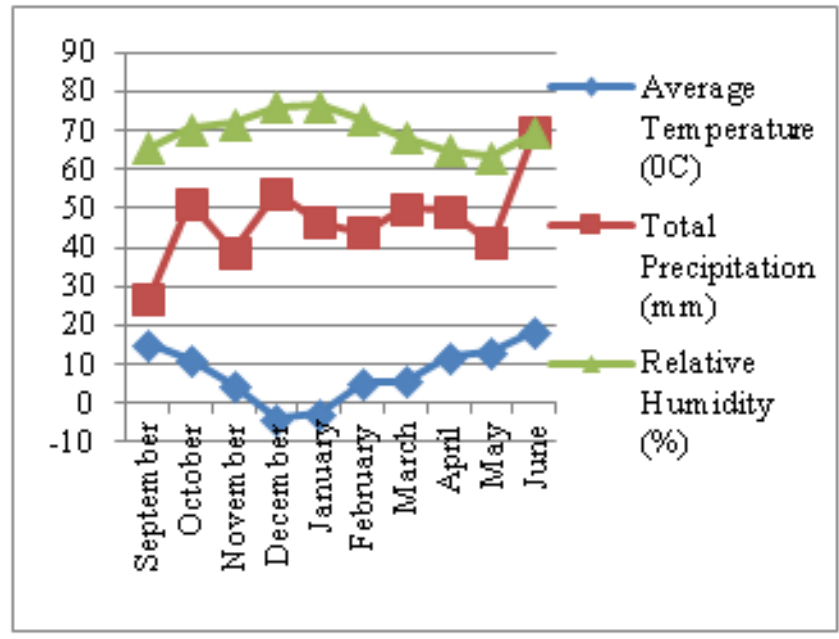

Figure 2. Climate data of 2016-17 period for the second environment (Sivas) where the experiment was conducted 


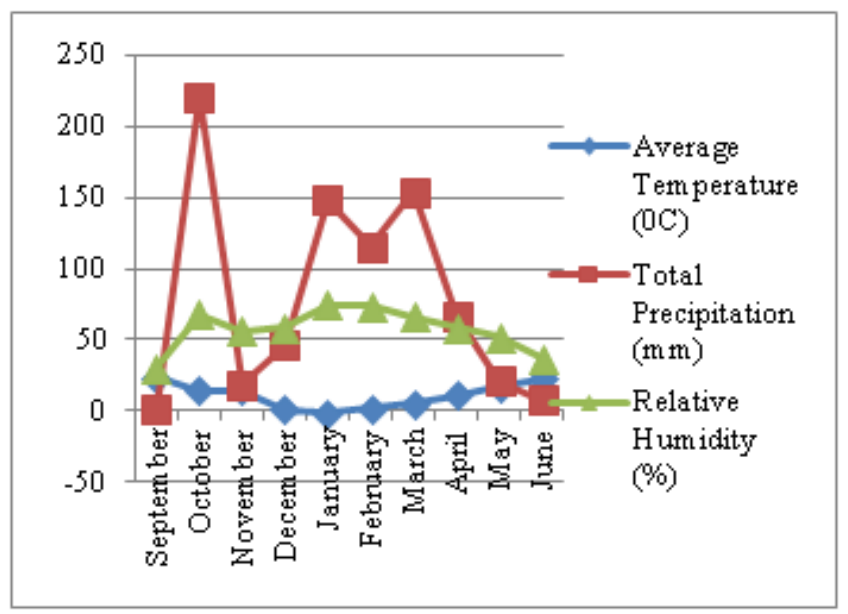

Figure 3. Climate data of 2016-17 period for the 3 rd environment (Bingöl) where the experiment was conducted

Seed yield and yield components were made during the period when the plants were completely yellow (about 180-200 days after sowing). The number of pods per plant (pieces/plant), the number of pods in this plant, the seeds of these beans were divided and counted, and the number of seeds (pieces) in pods was found. Then the whole of the parcels was weighed and the biological yield $\left(\mathrm{kg} \mathrm{da}^{-1}\right)$ was calculated, the grains were blended and weighed and the seed yield $\left(\mathrm{kg} \mathrm{da}^{-1}\right)$ was found. Straw yield (kg da-1) was calculated by removing seed yield from biological yield. However, harvest index (\%): seed yield $\times 100 /$ biological yield as calculated. By multiplying the weights of 100 seeds taken from each repetition 4 by 10 , the seeds of each species were determined with a weight of 1000 grains.

\section{Data processing}

The findings obtained from the study were subjected to variance analysis by using MstatC program. Duncan test was used to determine whether the difference between the averages is significant. Biplot (Genotype $+\mathrm{GxE}$ interaction) model analysis was performed using SPSS-16 packet program.

\section{Results and discussion}

In this study; values for various observed traits are presented in Table 2 and statistically significant differences between the lines and varieties in terms of natural plant height in all three locations were observed. Maximum plant height at Bilecik location was obtained from Kralkizi genotype with a value of $49.10 \mathrm{~cm}$, and the shortest plant height was obtained from Kubilay genotype with a value of $22.67 \mathrm{~cm}$. At the Bingol and Sivas locations, maximum plant height was resulted by Dicle genotype with the values of 52.47 and $54.13 \mathrm{~cm}$, respectively, while the minimum plant height was obtained from the Hat-7 genotype with 38.33 and $39.77 \mathrm{~cm}$ respectively. In Sivas, high rainfall $(154.8 \mathrm{~mm})$ and high relative humidity (66.0\%), especially in May, increased the plant height, so the plant height in Sivas was higher than other locations. The average plant height of the common vetch lines and varieties were not found to be statistically significant. Mean plant height ranged between 35.46 and $50.42 \mathrm{~cm}$ during 
this study. The study conducted by Kokten (2011) in Bingol dry conditions showed that the average plant height of the common vetch lines and varieties was $22.4 \mathrm{~cm}$. Although these results are different from our study, however results of this study made a strong agreement with the findings of Seydosoglu (2014) using the vetch genotypes and conducted experiment in same province and resulted plant height $33.9-62.6 \mathrm{~cm}$.

Table 2. Bilecik, Sivas and Bingol ecological conditions obtained from different common vetch genotypes, environment, and those interactions of average number of the height of the natural plant, pod numbers of per plant and seed numbers per pod

\begin{tabular}{|c|c|c|c|c|c|c|c|c|c|c|c|c|}
\hline \multirow{2}{*}{ Genotypes } & \multicolumn{4}{|c|}{ Natural plant height $(\mathrm{cm})$} & \multicolumn{4}{|c|}{ Pod numbers of per plant } & \multicolumn{4}{|c|}{ Seed numbers per pod } \\
\hline & Bilecik & Bingol & Sivas & Avg. & Bilecik & Bingol & Sivas & Avg. & Bilecik & Bingol & Sivas & Avg. \\
\hline Kralkizi & $49.10 \mathrm{a}$ & $27.87 \mathrm{~d}$ & $29.40 \mathrm{e}$ & 35.46 & $13.37 d-f$ & $10.47 \mathrm{~d}$ & $7.60 \mathrm{de}$ & $10.48 \mathrm{~d}$ & 6.30 & $4.73 \mathrm{ab}$ & 4.07 & 5.03 \\
\hline Dicle & $44.67 \mathrm{a}-\mathrm{c}$ & $52.47 \mathrm{a}$ & $54.13 \mathrm{a}$ & 50.42 & $20.43 b c$ & $18.00 \mathrm{bc}$ & $14.33 \mathrm{c}$ & $17.72 \mathrm{bc}$ & 6.43 & $4.87 \mathrm{ab}$ & 5.20 & 5.50 \\
\hline Gorkem & $30.57 b-d$ & $46.73 a-c$ & $47.97 \mathrm{a}-\mathrm{d}$ & 41.76 & $15.50 \mathrm{c}-\mathrm{f}$ & $12.43 \mathrm{~d}$ & $9.80 \mathrm{c}-\mathrm{e}$ & $12.58 \mathrm{~d}$ & 6.00 & $4.30 \mathrm{a}-\mathrm{c}$ & 5.53 & 5.28 \\
\hline Ozveren & $34.53 \mathrm{a}-\mathrm{d}$ & $44.93 \mathrm{a}-\mathrm{c}$ & $46.03 \mathrm{a}-\mathrm{d}$ & 41.83 & $16.20 \mathrm{c}-\mathrm{e}$ & $11.67 d$ & $6.67 \mathrm{e}$ & $11.51 \mathrm{~d}$ & 6.00 & $4.27 \mathrm{a}-\mathrm{c}$ & 5.93 & 5.40 \\
\hline Cumh.-99 & $35.10 \mathrm{a}-\mathrm{d}$ & $45.27 \mathrm{a}-\mathrm{c}$ & $46.87 \mathrm{a}-\mathrm{d}$ & 42.41 & $18.70 b-d$ & $14.40 \mathrm{~b}-\mathrm{d}$ & $12.80 \mathrm{c}-\mathrm{e}$ & $15.30 \mathrm{~b}-\mathrm{d}$ & 4.53 & $2.97 \mathrm{~d}$ & 3.33 & 3.61 \\
\hline Alinoglu & $40.70 \mathrm{a}-\mathrm{c}$ & $42.00 \mathrm{bc}$ & $43.53 \mathrm{c}-\mathrm{d}$ & 42.08 & $17.87 \mathrm{c}-\mathrm{e}$ & $13.37 \mathrm{~cd}$ & $12.40 \mathrm{c}-\mathrm{e}$ & $14.54 \mathrm{~cd}$ & 6.20 & $4.57 \mathrm{a}-\mathrm{c}$ & 4.47 & 5.08 \\
\hline Selcuk & $27.27 \mathrm{~cd}$ & $45.33 \mathrm{a}-\mathrm{c}$ & $46.93 \mathrm{a}-\mathrm{d}$ & 39.84 & $17.13 \mathrm{c}-\mathrm{e}$ & $12.70 \mathrm{~d}$ & $11.00 \mathrm{c}-\mathrm{e}$ & $13.61 \mathrm{~d}$ & 6.77 & $5.37 \mathrm{a}$ & 5.33 & 5.82 \\
\hline Kubilay & $22.67 d$ & $49.67 \mathrm{ab}$ & $51.40 \mathrm{a}-\mathrm{c}$ & 41.24 & $23.37 \mathrm{~b}$ & $18.70 \mathrm{~b}$ & $24.30 \mathrm{~b}$ & $22.12 b$ & 5.97 & $4.43 \mathrm{a}-\mathrm{c}$ & 6.40 & 5.60 \\
\hline Hat-1 & $31.73 \mathrm{a}-\mathrm{d}$ & $39.67 \mathrm{c}$ & $41.10 \mathrm{~d}$ & 37.50 & $16.73 \mathrm{c}-\mathrm{e}$ & $12.47 \mathrm{~d}$ & $9.00 \mathrm{c}-\mathrm{e}$ & $12.73 \mathrm{~d}$ & 5.30 & $3.70 \mathrm{~b}-\mathrm{d}$ & 3.20 & 4.07 \\
\hline Hat-7 & $31.23 \mathrm{a}-\mathrm{d}$ & $38.33 \mathrm{c}$ & $39.77 \mathrm{~d}$ & 36.44 & $34.30 \mathrm{a}$ & $29.73 a$ & $35.00 \mathrm{a}$ & $33.01 \mathrm{a}$ & 4.73 & $3.37 \mathrm{~cd}$ & 4.73 & 4.28 \\
\hline Hat-8 & $44.30 \mathrm{a}-\mathrm{c}$ & $41.07 \mathrm{bc}$ & $44.30 \mathrm{bc}$ & 43.22 & $15.93 \mathrm{c}-\mathrm{f}$ & $15.33 b-d$ & $14.00 \mathrm{c}$ & $15.09 \mathrm{~b}-\mathrm{d}$ & 5.30 & $3.47 \mathrm{~cd}$ & 5.33 & 4.70 \\
\hline Hat-13 & $47.80 \mathrm{ab}$ & $40.27 \mathrm{c}$ & $43.87 \mathrm{~cd}$ & 43.98 & $12.27 \mathrm{ef}$ & $13.97 \mathrm{~b}-\mathrm{d}$ & $10.13 \mathrm{c}-\mathrm{e}$ & $12.12 \mathrm{~b}-\mathrm{d}$ & 5.40 & $4.03 b-d$ & 5.47 & 4.97 \\
\hline Hat-17 & $44.07 \mathrm{a}-\mathrm{c}$ & $49.87 \mathrm{ab}$ & $53.23 \mathrm{ab}$ & 49.06 & $10.53 \mathrm{f}$ & $12.47 \mathrm{~d}$ & $13.30 \mathrm{~cd}$ & $12.10 \mathrm{~d}$ & 5.13 & $3.93 \mathrm{~b}-\mathrm{d}$ & 4.47 & 4.51 \\
\hline Average & 37.21 & 43.34 & 45.27 & & $17.87 \mathrm{~A}$ & $15.05 \mathrm{AB}$ & $13.90 \mathrm{~B}$ & & $5.70 \mathrm{~A}$ & $4.15 \mathrm{~B}$ & $4.88 \mathrm{AB}$ & \\
\hline LSD & 15.60 & 7.879 & 7.959 & & 5.009 & 4.553 & 5.348 & 4.553 & & 1.062 & & \\
\hline LSD (lok) & & & & & & 1.223 & & & & 1.223 & & \\
\hline $\mathrm{CV}(\%)$ & 25.36 & 11.01 & 10.64 & 15.99 & 16.96 & 18.30 & 23.27 & 19.31 & 13.04 & 15.47 & 17.97 & 15.48 \\
\hline
\end{tabular}

In the same column, the averages indicated by similar group of letters are not different from Duncan $(5 \%)$

In terms of the numbers of pods per plant, statistically significant differences were observed between the lines and varieties at all three locations. In Bilecik, Bingol and Sivas locations, the highest numbers of pods per plant was obtained from Hat-7 genotype with 34.30, 29.73 and 35.00 values respectively, while the lowest numbers of pods per plant was found at Bilecik location; 10.53 value byHat-17 genotype, Bingol location; It was obtained from the Kralkizi genotype with 10.47 and the Ozveren genotype with 6.67 in Sivas location. The average of numbers of pods per plant by common vetch lines and varieties was found to be statistically significant, while the numbers of pods per plant was obtained from the genus Hat-7 with a value of 33.01, while the lowest numbers of pods per plant was obtained from Ozveren genotype with a value of 11.51. In addition, the interaction of locations and location $\mathrm{x}$ genotype was found to be statistically significant. The highest numbers of pods per plant in Bilecik (17.87 units) was obtained, followed by Bingol location (15.05 units) and the lowest numbers of pods per plant were obtained from Sivas (13.90 units).

Statistically significant differences for number of seed per pod between the lines and varieties were observed in Bingol location. However, there were no statistically significant differences between the lines and varieties in the locations of Bilecik and Sivas. In the location of Bilecik; number of seed per pod ranged from 4.53 to 6.43. In Sivas, number of seed per pod varied between 3.33 and 6.40. In Bingol location, the 
highest number of seed per pod was obtained from Selcuk genotype with a value of 5.37, while the number of seed per pod was obtained from the Cumhuriyet-99 genotype with a value of 2.97. In addition, while the averages of the locations were statistically insignificant, the interaction of locations and location $\mathrm{x}$ genotype was found to be statistically significant. The highest number of seed per pod was obtained in Bilecik (5.70), followed by Sivas (4.88) and the lowest seed number per pod were obtained from Bingol (4.15).

Higher temperature with greater relative humidity at the Bilecik location during the period of study resulted in maximum number of pods and the number of seeds in the pods to be higher than the other locations. In addition, as Fehr (1987) stated, it is natural for the study to be different because of the opinion that the environment can have different effects on the same species and variety and differences in their performances can be observed.

Albayrak et al. (2004) used various vetch varieties and lines by conducting multi location experiments and resulted number of seeds per pod for varieties 6.11-8.44 and 5.44 to 7.22 for lines. Seydosoglu, in his study in 2014 founded seed number per pod in a range of 13.5-21.2, the seed number per pod varies between 4.7-5.6 units (Seydosoglu, 2014). These studies seem to be in harmony with our work.

The average value of forage yield and dry matter yield obtained from common vetch lines and varieties used in Bilecik, Bingol and Sivas locations are presented in Table 3.

Table 3. Bilecik, Sivas and Bingol ecological conditions obtained from different common vetch genotypes, environment, and those interactions of average values of forage yield and dry matter yield

\begin{tabular}{c|c|c|c|c|c|c|c|c}
\hline \multirow{2}{*}{ Genotypes } & \multicolumn{4}{|c}{ Forage yield $\left(\mathbf{k g ~ d a}^{-1}\right)$} & \multicolumn{4}{c}{ Dry matter yield (kg da-1) } \\
\cline { 2 - 9 } & Bilecik & Bingol & Sivas & Average & Bilecik & Bingol & Sivas & Average \\
\hline Kralkizi & $3733.30 \mathrm{a}$ & $412.67 \mathrm{~g}$ & $653.10 \mathrm{~g}$ & 1599.69 & $964.47 \mathrm{ab}$ & $92.70 \mathrm{f}$ & $230.37 \mathrm{f}$ & 429.18 \\
Dicle & $3400.00 \mathrm{a}-\mathrm{d}$ & $932.53 \mathrm{a}$ & $1172.87 \mathrm{a}$ & 1835.14 & $1107.13 \mathrm{a}$ & $217.83 \mathrm{a}$ & $355.57 \mathrm{a}$ & 560.18 \\
Gorkem & $2866.67 \mathrm{de}$ & $841.13 \mathrm{~b}$ & $1081.77 \mathrm{~b}$ & 1596.52 & $596.33 \mathrm{ab}$ & $196.07 \mathrm{a}-\mathrm{c}$ & $314.07 \mathrm{~b}$ & 368.82 \\
Ozveren & $3066.67 \mathrm{a}-\mathrm{e}$ & $766.90 \mathrm{~b}-\mathrm{d}$ & $1007.50 \mathrm{~b}-\mathrm{d}$ & 1613.69 & $880.57 \mathrm{ab}$ & $176.37 \mathrm{~b}-\mathrm{d}$ & $284.93 \mathrm{~b}-\mathrm{d}$ & 444.29 \\
Cumh.-99 & $3025.33 \mathrm{~b}-\mathrm{e}$ & $823.77 \mathrm{bc}$ & $1064.17 \mathrm{bc}$ & 1637.76 & $727.70 \mathrm{ab}$ & $201.70 \mathrm{ab}$ & $310.30 \mathrm{bc}$ & 413.23 \\
Alinoglu & $3711.10 \mathrm{ab}$ & $701.23 \mathrm{de}$ & $941.83 \mathrm{de}$ & 1784.72 & $984.57 \mathrm{ab}$ & $162.97 \mathrm{de}$ & $271.63 \mathrm{de}$ & 473.06 \\
Selcuk & $2900.00 \mathrm{c}-\mathrm{e}$ & $739.43 \mathrm{~cd}$ & $979.63 \mathrm{~cd}$ & 1539.69 & $596.67 \mathrm{ab}$ & $172.63 \mathrm{~b}-\mathrm{d}$ & $281.27 \mathrm{~b}-\mathrm{e}$ & 350.19 \\
Kubilay & $2630.00 \mathrm{e}$ & $795.57 \mathrm{~b}-\mathrm{d}$ & $1036.27 \mathrm{~b}-\mathrm{d}$ & 1487.28 & $528.77 \mathrm{~b}$ & $169.03 \mathrm{c}-\mathrm{e}$ & $277.74 \mathrm{c}-\mathrm{e}$ & 325.18 \\
Hat-1 & $3585.50 \mathrm{a}-\mathrm{c}$ & $644.33 \mathrm{ef}$ & $884.90 \mathrm{ef}$ & 1700.47 & $1003.50 \mathrm{ab}$ & $182.57 \mathrm{~b}-\mathrm{d}$ & $291.10 \mathrm{~b}-\mathrm{d}$ & 492.39 \\
Hat-7 & $3140.80 \mathrm{a}-\mathrm{e}$ & $610.10 \mathrm{ef}$ & $850.67 \mathrm{ef}$ & 1533.86 & $698.70 \mathrm{ab}$ & $159.73 \mathrm{de}$ & $268.23 \mathrm{de}$ & 375.56 \\
Hat-8 & $3418.57 \mathrm{a}-\mathrm{d}$ & $631.57 \mathrm{ef}$ & $872.33 \mathrm{ef}$ & 1640.82 & $821.87 \mathrm{ab}$ & $176.17 \mathrm{~b}-\mathrm{d}$ & $284.40 \mathrm{~b}-\mathrm{d}$ & 427.48 \\
Hat-13 & $3100.00 \mathrm{a}-\mathrm{e}$ & $579.90 \mathrm{f}$ & $820.50 \mathrm{f}$ & 1500.13 & $921.17 \mathrm{ab}$ & $142.37 \mathrm{e}$ & $250.57 \mathrm{ef}$ & 438.03 \\
Hat-17 & $3025.43 \mathrm{~b}-\mathrm{e}$ & $802.80 \mathrm{bc}$ & $1043.53 \mathrm{bc}$ & 1623.92 & $834.53 \mathrm{ab}$ & $202.60 \mathrm{ab}$ & $310.83 \mathrm{bc}$ & 449.32 \\
Average & $3200.26 \mathrm{~A}$ & $714.00 \mathrm{~B}$ & $953.51 \mathrm{~B}$ & & $820.50 \mathrm{~A}$ & $173.29 \mathrm{~B}$ & $286.30 \mathrm{~B}$ & \\
LSD & 595.8 & 87.54 & 87.47 & & 433.5 & 27.29 & 29.62 & \\
LSD(lok) & & 355.0 & & & & 247.2 & & \\
CV (\%) & 11.26 & 7.42 & 5.54 & 13.13 & 31.97 & 9.53 & 6.24 & 35.67 \\
\hline
\end{tabular}

In the same column, the averages indicated by similar group of letters are not different from Duncan (5\%)

As seen in Table 3, there are statistically significant differences between genotypes in all three locations in terms of forage yield, and it is also observable that there are no statistical differences in the averages where the locations are combined. In addition, the 
interaction of locations and GEI was found to be statistically significant. The highest forage yield was obtained from the Kralkizi genotype with a value of $3733.30 \mathrm{~kg} \mathrm{da}^{-1}$, while the lowest forage yield was obtained from the Kubilay genotype with a value of $2630.00 \mathrm{~kg} \mathrm{da}^{-1}$. In Bingol and Sivas, respectively, it was obtained from Dicle genotype with 932.53 and $1172.87 \mathrm{~kg} \mathrm{da}^{-1}$ values, and the lowest forage yield was obtained from Kralkizi genotype with 412.67 and $653.10 \mathrm{~kg} \mathrm{da}^{-1}$ values. On average, the forage yield varied between 1487.28 and $1835.14 \mathrm{~kg} \mathrm{da}^{-1}$. In addition, the highest forage yield was obtained from Bilecik (3200.26 kg da $\left.{ }^{-1}\right)$, while the lowest forage yield was obtained from Bingol location (714.00 $\left.\mathrm{kg} \mathrm{da}^{-1}\right)$.

High temperature with greater relative humidity during the study periods at Bilecik location resulted in higher forage yield as compared to rest of locations. It can be seen that environmental differences such as temperature, relative humidity and precipitation have caused the efficiency of common vetch genotypes to be different in the locations where the study was conducted. According to Gramsh (1982), performance of vetch varieties for forage yield is largely dependent upon the region and its climatic conditions.

In terms of dry matter yield; statistically significant differences between genotypes in all three locations were observed, and it was found that there were no statistical differences in the averages of all the locations when combined. In addition, genotypes and GEI was found to be statistically significant. The highest dry matter yield was obtained from the Dicle genotype with the values of $1107.13,217.83$ and $355.57 \mathrm{~kg} \mathrm{da}^{-1}$ in Bilecik, Bingol and Sivas locations, respectively, the lowest dry matter yield in the Bilecik location, the Kubilay genotype with $528.77 \mathrm{~kg} \mathrm{da}^{-1}$ value, Bingol and Sivas and 92.32 and $230.37 \mathrm{~kg} \mathrm{da}^{-1}$ respectively. On average, the dry matter yields varied between 325.18 and $560.18 \mathrm{~kg} \mathrm{da}^{-1}$. In addition, the highest dry matter yield was obtained from the Bilecik location $\left(820.50 \mathrm{~kg} \mathrm{da}^{-1}\right)$, while the lowest dry matter yield was obtained from Bingol location (173.29 $\mathrm{kg} \mathrm{da}^{-1}$ ). Similarly to this study, Seydosoglu, in his study in 2014 in the Diyarbakir; stated that forage yield can be vary between 1522.0$3232.3 \mathrm{~kg} \mathrm{da}^{-1}$ and dry matter yield between 308.0-919.5 kg da ${ }^{-1}$. Mikic et al. (2014) found $8.8 \mathrm{t} \mathrm{ha}^{-1}$ as 2 years averaged DM yield which varied between $8.0 \mathrm{t} \mathrm{DM} \mathrm{ha}^{-1}$ (cvs. Armantes and Labari) and $10.2 \mathrm{t} \mathrm{ha}^{-1}$ (cv. Slavej). These findings are consistent with our findings.

The average value of biological yield and straw yield obtained from common vetch lines and varieties used in Bilecik, Bingol and Sivas locations are presented in Table 4.

As it can be seen in Table 4, there are statistically significant differences between genotypes in all three locations where the study is conducted and there is no statistically significant difference between the averages where the locations are combined. In addition, the interaction of locations and location $\mathrm{x}$ genotype was found to be statistically significant. The highest biological yield was obtained from Kralkizi genotype with $1288.67 \mathrm{~kg} \mathrm{da}^{-1}$ value at Bilecik location, while the lowest biological yield was obtained from Kubilay genotype with $335.67 \mathrm{~kg} \mathrm{da}^{-1}$ value. At the Bingol and Sivas locations, the highest biological yield was obtained from the Cumhuriyet-99 genotype with the values of 335.60 and $356.13 \mathrm{~kg} \mathrm{da}^{-1}$ respectively, while the lowest biological yield was obtained from the Kralkizi genotype with 153.63 and $174.50 \mathrm{~kg} \mathrm{da}^{-1}$ values respectively. Biological yields ranged between 320.30 and $538.93 \mathrm{~kg} \mathrm{da}^{-1}$ in the averages of locations. In addition, the highest biological yield was obtained from the Bilecik location (706.95 $\left.\mathrm{kg} \mathrm{da}^{-1}\right)$, while the lowest biological yield was obtained from the Bingol location $\left(268.51 \mathrm{~kg} \mathrm{da}^{-1}\right)$. 
In terms of straw yield efficiency, statistically significant differences between genotypes in all three locations were observed, and it was also observed that there were no statistical differences in the averages where the locations were combined. Additionally, genotypes and GEI was also found to be statistically significant. Maximum straw yield was obtained from Kralkizi genotype (1154.00 $\left.\mathrm{kg} \mathrm{da}^{-1}\right)$ at Bilecik location, the lowest straw yield was obtained from Kubilay genotype with $204.00 \mathrm{~kg} \mathrm{da}^{-1}$ values. In Bingol and Sivas locations, respectively, it is obtained from Gorkem genotype with 271.87 and $348.73 \mathrm{~kg} \mathrm{da}^{-1}$ values, the lowest straw yield is in Bingol location, with $106-180 \mathrm{~kg} \mathrm{da}^{-1}$ Kralkizi genotype and in Sivas location with $198.87 \mathrm{~kg} \mathrm{da}^{-1}$ values genotype. The straw yields for all locations combined ranged from 255.27 to $486.84 \mathrm{~kg} \mathrm{da}^{-1}$. In addition, the maximum straw yield was obtained from Bilecik location $\left(552.33 \mathrm{~kg} \mathrm{da}^{-1}\right)$, while the lowest straw yield was obtained from Bingol location $\left(211.84 \mathrm{~kg} \mathrm{da}^{-1}\right)$.

Table 4. Bilecik, Sivas and Bingol ecological conditions obtained from different common vetch genotypes, environment, and those interactions of average values of biological yield and straw yield

\begin{tabular}{c|c|c|c|c|c|c|c|c}
\hline \multirow{2}{*}{ Genotypes } & \multicolumn{4}{|c|}{ Biological yield $\left(\mathbf{k g ~ d a}^{-1}\right)$} & \multicolumn{4}{c}{ Straw yield $\left(\mathbf{k g ~ d a}^{-1}\right)$} \\
\cline { 2 - 9 } & Bilecik & Bingol & Sivas & Average & Bilecik & Bingol & Sivas & Average \\
\hline Kralkizi & $1288.67 \mathrm{a}$ & $153.63 \mathrm{~h}$ & $174.50 \mathrm{~h}$ & 538.93 & $1154.00 \mathrm{a}$ & $106.80 \mathrm{~g}$ & $199.73 \mathrm{f}$ & 486.84 \\
Dicle & $666.70 \mathrm{~cd}$ & $287.87 \mathrm{~cd}$ & $308.67 \mathrm{~cd}$ & 421.07 & $529.67 \mathrm{c}$ & $241.37 \mathrm{bc}$ & $334.07 \mathrm{ab}$ & 368.37 \\
Gorkem & $377.70 \mathrm{e}$ & $327.03 \mathrm{ab}$ & $347.50 \mathrm{ab}$ & 350.73 & $236.33 \mathrm{de}$ & $271.87 \mathrm{a}$ & $348.73 \mathrm{a}$ & 285.64 \\
Ozveren & $822.33 \mathrm{bc}$ & $272.10 \mathrm{de}$ & $292.47 \mathrm{de}$ & 462.30 & $632.67 \mathrm{bc}$ & $211.10 \mathrm{de}$ & $257.87 \mathrm{de}$ & 367.21 \\
Cumh.-99 & $977.67 \mathrm{~b}$ & $335.60 \mathrm{a}$ & $356.13 \mathrm{a}$ & 556.47 & $836.00 \mathrm{~b}$ & $271.43 \mathrm{a}$ & $317.77 \mathrm{bc}$ & 467.30 \\
Alinoglu & $733.33 \mathrm{~cd}$ & $306.17 \mathrm{bc}$ & $326.53 \mathrm{bc}$ & 455.34 & $580.67 \mathrm{bc}$ & $232.00 \mathrm{~cd}$ & $278.53 \mathrm{~d}$ & 363.73 \\
Selcuk & $789.00 \mathrm{bc}$ & $302.33 \mathrm{c}$ & $323.23 \mathrm{c}$ & 471.52 & $625.67 \mathrm{bc}$ & $257.67 \mathrm{ab}$ & $304.40 \mathrm{c}$ & 384.80 \\
Kubilay & $335.67 \mathrm{e}$ & $302.33 \mathrm{c}$ & $322.90 \mathrm{c}$ & 320.30 & $204.00 \mathrm{e}$ & $257.67 \mathrm{ab}$ & $304.13 \mathrm{c}$ & 255.27 \\
Hat-1 & $644.67 \mathrm{~cd}$ & $228.83 \mathrm{f}$ & $249.33 \mathrm{f}$ & 374.28 & $493.33 \mathrm{~cd}$ & $161.33 \mathrm{f}$ & $207.83 \mathrm{f}$ & 287.50 \\
Hat-7 & $622.00 \mathrm{~cd}$ & $253.57 \mathrm{e}$ & $273.97 \mathrm{e}$ & 383.38 & $459.67 \mathrm{c}-\mathrm{e}$ & $197.57 \mathrm{e}$ & $244.20 \mathrm{e}$ & 300.48 \\
Hat-8 & $533.00 \mathrm{de}$ & $263.23 \mathrm{e}$ & $284.03 \mathrm{e}$ & 360.10 & $397.33 \mathrm{c}-\mathrm{e}$ & $198.90 \mathrm{e}$ & $245.40 \mathrm{e}$ & 280.54 \\
Hat-13 & $722.00 \mathrm{~cd}$ & $193.63 \mathrm{~g}$ & $214.13 \mathrm{~g}$ & 376.60 & $518.33 \mathrm{c}$ & $152.13 \mathrm{f}$ & $198.87 \mathrm{f}$ & 289.78 \\
Hat-17 & $677.67 \mathrm{~cd}$ & $264.27 \mathrm{e}$ & $284.90 \mathrm{e}$ & 408.94 & $546.00 \mathrm{c}$ & $194.10 \mathrm{e}$ & $240.77 \mathrm{e}$ & 326.96 \\
Average & $706.95 \mathrm{~A}$ & $268.51 \mathrm{~B}$ & $289.14 \mathrm{~B}$ & & $552.33 \mathrm{~A}$ & $211.84 \mathrm{~B}$ & $266.07 \mathrm{~B}$ & \\
LSD & 219.8 & 22.12 & 22.30 & & 240.6 & 20.93 & 23.70 & \\
LSD(lok) & & 127.9 & & & & 134.6 & & \\
CV & 18.81 & 4.98 & 4.67 & 18.39 & 26.23 & 5.98 & 5.35 & 23.84 \\
\hline
\end{tabular}

In the same column, the averages indicated by similar group of letters are not different from Duncan $(5 \%)$

According to Unal et al. (2016) differences in the performance of genotypes at different locations may be due to abiotic (climatic features, soil properties and topography) and biotic factors (weed, pest and diseases) at the specific location. During this study, temperature and precipitation were found highly variable over all three locations and highly influenced the plant growth, yield and production potentials of vetch plant. Results of this study made a strong agreement with the findings of Albayrak et al. (2004) resulting biological yield between 584 to $729 \mathrm{~kg} \mathrm{da}^{-1}$ under multilocations. 
The average value of seed yield, thousand seed weight and harvest index obtained from common vetch lines and varieties used in Bilecik, Bingol and Sivas locations are given in Table 5 .

Table 5. Bilecik, Sivas and Bingol ecological conditions obtained from different common vetch genotypes, environment, and those interactions of average values of seed yield, thousand seed weight and harvest index

\begin{tabular}{|c|c|c|c|c|c|c|c|c|c|c|c|c|}
\hline \multirow{2}{*}{ Genotypes } & \multicolumn{4}{|c|}{ Seed yield $\left(\mathrm{kg} \mathrm{da}^{-1}\right)$} & \multicolumn{4}{|c|}{ Thousand seed weight (gr) } & \multicolumn{4}{|c|}{ Harvest index (\%) } \\
\hline & Bilecik & Bingol & Sivas & Average & Bilecik & Bingol & Sivas & Average & Bilecik & Bingol & Sivas & Average \\
\hline Kralkizi & 134.67 & $46.83 \mathrm{e}$ & $55.57 \mathrm{e}$ & 79.02 & $64.13 \mathrm{bc}$ & $46.43 \mathrm{~cd}$ & $62.20 \mathrm{~b}$ & 57.59 & 34.67 & $30.53 \mathrm{a}$ & $48.73 \mathrm{~cd}$ & 29.98 \\
\hline Dicle & 137.00 & $46.50 \mathrm{e}$ & $55.17 \mathrm{e}$ & 79.56 & $56.33 \mathrm{f}$ & $46.07 \mathrm{c}-\mathrm{e}$ & $61.57 \mathrm{bc}$ & 54.66 & 20.50 & $16.13 \mathrm{f}$ & $35.00 \mathrm{f}$ & 23.88 \\
\hline Gorkem & 141.33 & $55.17 \mathrm{~d}$ & $63.43 \mathrm{~d}$ & 86.64 & $50.60 \mathrm{~g}$ & $42.10 \mathrm{e}$ & $57.33 \mathrm{~b}-\mathrm{d}$ & 50.01 & 40.07 & $16.90 \mathrm{ef}$ & $35.40 \mathrm{f}$ & 30.79 \\
\hline Ozveren & 189.67 & $61.00 \mathrm{~cd}$ & $69.40 \mathrm{~cd}$ & 106.69 & $69.87 \mathrm{a}$ & $53.80 \mathrm{a}$ & $69.13 \mathrm{a}$ & 64.27 & 24.47 & $22.57 \mathrm{c}$ & $41.03 \mathrm{e}$ & 29.36 \\
\hline Cumh.-99 & 141.67 & $64.17 \mathrm{bc}$ & $72.60 \mathrm{bc}$ & 92.81 & $61.80 \mathrm{~cd}$ & $52.37 \mathrm{ab}$ & $68.00 \mathrm{a}$ & 60.72 & 15.23 & $19.17 \mathrm{de}$ & $37.37 f$ & 23.92 \\
\hline Alinoglu & 152.67 & $74.17 \mathrm{a}$ & $82.67 \mathrm{a}$ & 103.17 & $58.27 \mathrm{ef}$ & $53.67 \mathrm{a}$ & $68.93 \mathrm{a}$ & 60.29 & 21.13 & $24.23 \mathrm{bc}$ & $42.80 \mathrm{e}$ & 29.39 \\
\hline Selcuk & 196.67 & $44.67 \mathrm{e}$ & $53.23 \mathrm{e}$ & 98.19 & $58.60 \mathrm{~d}-\mathrm{f}$ & $42.50 \mathrm{de}$ & $58.13 \mathrm{bc}$ & 53.08 & 25.90 & $14.73 \mathrm{f}$ & $41.13 \mathrm{e}$ & 27.26 \\
\hline Kubilay & 131.67 & $44.67 \mathrm{e}$ & $52.97 \mathrm{e}$ & 76.43 & $58.33 \mathrm{ef}$ & $49.80 \mathrm{a}-\mathrm{c}$ & $59.97 \mathrm{bc}$ & 56.03 & 39.13 & $14.73 \mathrm{f}$ & $41.17 \mathrm{e}$ & 31.68 \\
\hline Hat-1 & 151.33 & $67.50 \mathrm{a}-\mathrm{c}$ & $76.10 \mathrm{a}-\mathrm{c}$ & 98.31 & $64.07 \mathrm{bc}$ & $48.87 \mathrm{bc}$ & $56.70 \mathrm{~cd}$ & 56.21 & 23.43 & $29.57 \mathrm{a}$ & $56.30 \mathrm{a}$ & 36.43 \\
\hline Hat-7 & 162.33 & $56.00 \mathrm{~d}$ & $64.73 \mathrm{~d}$ & 94.36 & $65.53 b$ & $45.80 \mathrm{c}-\mathrm{e}$ & $53.27 \mathrm{~d}$ & 54.87 & 26.53 & $22.07 \mathrm{~cd}$ & $48.50 \mathrm{~cd}$ & 32.37 \\
\hline Hat-8 & 135.67 & $64.33 b c$ & $73.13 b c$ & 91.04 & $65.80 \mathrm{~b}$ & $53.70 \mathrm{a}$ & $61.10 \mathrm{bc}$ & 60.20 & 25.43 & $24.47 \mathrm{bc}$ & $51.00 \mathrm{bc}$ & 33.63 \\
\hline Hat-13 & 203.67 & $41.50 \mathrm{e}$ & $50.00 \mathrm{e}$ & 98.39 & $61.23 \mathrm{c}-\mathrm{e}$ & $37.63 \mathrm{f}$ & $44.87 \mathrm{e}$ & 47.91 & 29.13 & $21.47 \mathrm{~cd}$ & $47.73 \mathrm{~d}$ & 32.78 \\
\hline Hat-17 & 131.67 & $70.17 \mathrm{ab}$ & $78.60 \mathrm{ab}$ & 93.48 & $59.60 \mathrm{~d}-\mathrm{f}$ & $53.60 \mathrm{a}$ & $61.00 \mathrm{bc}$ & 58.07 & 19.07 & $26.57 b$ & $53.10 \mathrm{~b}$ & 32.91 \\
\hline Average & $154.62 \mathrm{~A}$ & 56.67B & $65.20 \mathrm{~B}$ & & $61.01 \mathrm{~A}$ & $48.18 \mathrm{~B}$ & $60.17 \mathrm{~A}$ & & 24.67B & $21.78 \mathrm{~B}$ & $44.56 \mathrm{~A}$ & \\
\hline LSD & & 6.958 & 6.963 & & 3.062 & 3.826 & 4.449 & & & 2.770 & 2.928 & \\
\hline LSD (lok) & & 32.08 & & & & 3.88 & & & & 6.521 & & \\
\hline $\mathrm{CV}$ & 21.67 & 7.43 & 6.46 & 21.32 & 3.03 & 4.80 & 4.47 & 4.11 & 13.29 & 7.69 & 3.97 & 13.44 \\
\hline
\end{tabular}

In the same column, the averages indicated by similar group of letters are not different from Duncan $(5 \%)$

As seen in Table 5, there are statistically significant differences between genotypes in terms of seed yield in Bingol and Sivas locations, but there are no statistically significant differences between genotypes in Bilecik location. The seed yields of the genotypes at the location of Bilecik ranged between 131.67 and $203.67 \mathrm{~kg} \mathrm{da}^{-1}$. In the Bingol and Sivas locations, maximum seed yield was obtained from Alinoglu genotype with values of 74.17 and $82.67 \mathrm{~kg} \mathrm{da}^{-1}$, respectively, while the lowest seed yield was obtained from the genotype Hat-13 with the values of 41.50 and $50.00 \mathrm{~kg} \mathrm{da}^{-1}$. The differences between the common vetch lines were caused by variations in their genetic makeup. The averages of the common vetch genotypes were not found statistically significant and the seed yields varied between 76.43 and $106.69 \mathrm{~kg} \mathrm{da}^{-1}$. In addition, the location and genotype interaction were found to be statistically significant. However, the highest seed yield was obtained from Bilecik location $\left(154.62 \mathrm{~kg} \mathrm{da}^{-1}\right)$ while the lowest seed yield was obtained from Bingol location $\left(56.67 \mathrm{~kg} \mathrm{da}^{1}\right)$. In the Bilecik location, numbers of pods per plant and numbers of seeds per pod were higher than those of Bingol and Sivas locations. Albayrak et al. (2004) conducted multi locations experiments and stated that seed yield of common vetch can be varied between 98 $160 \mathrm{~kg} \mathrm{da}^{-1}$ and the one thousand grains weight ranged from 57.7 to $63.4 \mathrm{~g}$ and these results were found in line with the findings of this study. Similarly, our results were further supported by the findings of Gurmani et al. (2006) resulting seed yields in a range of 643.0 to $1620.0 \mathrm{~kg} \mathrm{ha}^{-1}$. In terms of one thousand seed weight, statistically significant differences between genotypes in all three locations were observed, and it is 
seen that there are no statistical differences in the averages where the locations are combined. In addition, the interaction of locations and location $\mathrm{x}$ genotype was found to be statistically significant. In Bilecik, Bingol and Sivas locations, the maximum thousand seed weight was obtained from Ozveren genotype with 69.87, 53.80 and $69.13 \mathrm{~g}$, respectively, while the lowest thousand seed weight was at Bilecik location; it was obtained from the Gorkem genotype with $50.60 \mathrm{~g}$ and from the Hat-13 genotype with 37.63 and $44.87 \mathrm{~g}$ values in Bingol and Sivas locations, respectively. In terms of one thousand seed weight, the average of the locations of common vetch genotypes ranged from 47.91 to $64.27 \mathrm{~g}$. In addition, a maximum of thousand seed weight was obtained from Bilecik location $(61.01 \mathrm{~g})$, followed by Sivas location $(60.17 \mathrm{~g})$, the lowest thousand seed weight from Bingol location (48.18 g). Possible reason behind these variations may be due to differences in the ecological conditions of studied locations. Orak and Nizam (2004) measured data of TSW were between 31.92 and $63.52 \mathrm{~g}$ and their findings clearly supported the results of this study.

There are statistically significant differences between genotypes in Bingol and Sivas locations in terms of harvest index, but there are no statistically significant differences between genotypes in Bilecik location. Harvest index of the genotypes at Bilecik location varied between $15.23 \%$ and $39.13 \%$. Maximum harvest index was obtained from the Kralkizi genotype with a value of $30.53 \%$, while the lowest harvest index was obtained from Selcuk and Kubilay genotypes with a value of $14.73 \%$ at the Bilecik location. In Sivas, the highest harvest index was obtained from Hat-1 genotype with a value of $56.30 \%$, while the lowest harvest index was obtained from the Dicle genotype with a value of $35.00 \%$. The average of the locations where common vetch genotypes were combined was not statistically significant, and the harvest index changed between $27.26 \%$ and $36.43 \%$. In addition, the location and genotype interactions were found to be statistically significant in terms of harvest index. However, the highest harvest index was obtained from Sivas location $(44.56 \%)$ while the lowest harvest index was obtained from Bingol location $(21.78 \%$ ). Hereby, the high seed yield naturally results in greater HI. Unal et al. (2016) found that the harvest index for common vetch can vary between 39.23 and $42.54 \%$ and their findings made strong agreement with the results of this study.

Determination of ideal properties with biplot method in Bilecik, Bingol and Sivas locations are given in Figure 4.

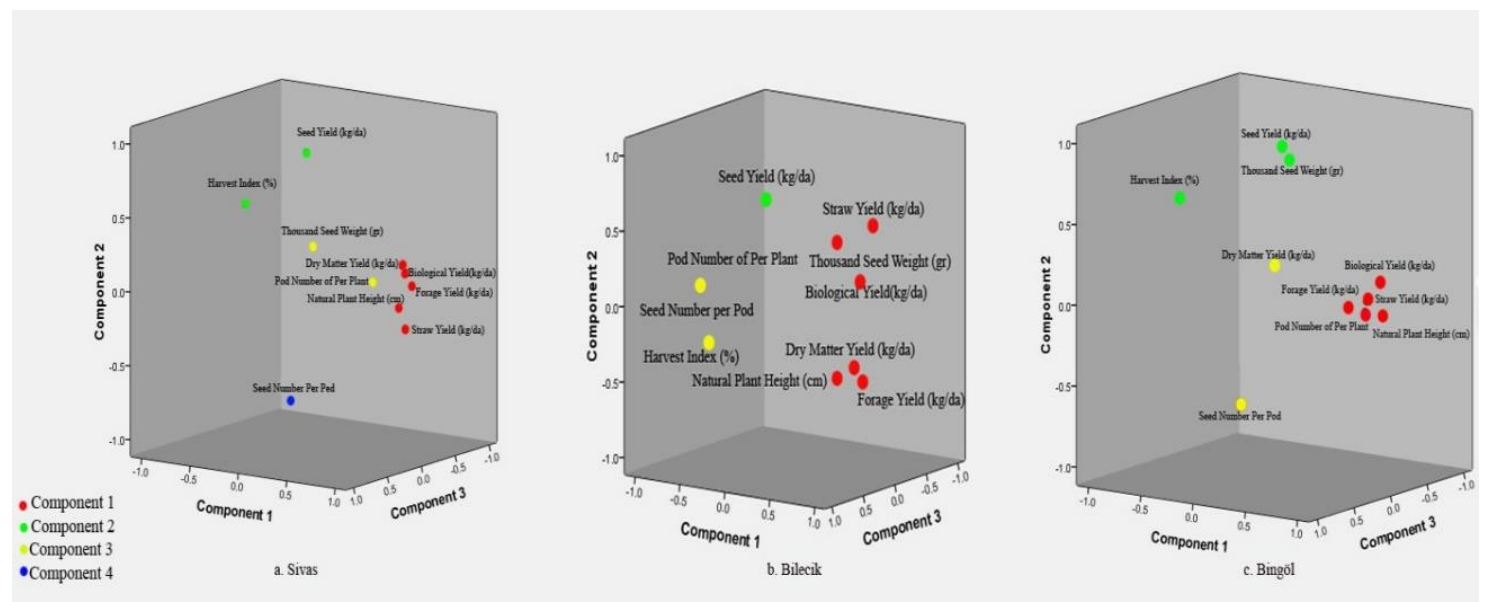

Figure 4. Determination of ideal properties with biplot method in different locations 
Biplot analysis is considered one of the most easiest and effective way to select genotypes reflecting superior performance for various traits of interest under multi environments/locations. In this study, biplot analysis was evaluated for each location to evaluate differences for studied traits. It was observable that biological yield, forage yield and straw yield were found main variations contributing factors in component 1 at all three studied locations. However, some differences were present in each location for component two and three for few traits. It is observable that harvest index, seed number per pod and thousand seed weight are changing among the location. Therefore, it can be suggested that good understanding about the behaviour of these traits under multi environmental condition will be helpful in breeding activities. Seed yield is most important trait for any crop and can be used as selection criteria to evaluate genotypes having superior performance. Seed yield was found main contributor in component two in all three locations. Therefore, this trait can be suggested for the selection of genotypes.

Principal component analysis (PCA) was performed to understand the level of variations and importance was given to 1 st four components because they accounted maximum variations at the first location (Fig. 4a). In the first component, 5 important variables are Forage Yield (0.963), Straw Yield (0.949), Biological Yield (0.909), Dry Matter Yield (0.836) and Natural Plant Height (0.818), respectively, and the second component is Seed Yield (0.934) and Harvest Index (0.454). The third component included Thousand Seed Weight (0.627) and Seed Number per Pod (0.592) and the fourth component included Pod Number of Per Plant (0.651).

Three components were identified at the second location (Fig. 4b). In the first component, Dry Matter Yield (0.802), Biological Yield (0.787), Straw Yield (0.771), Forage Yield (0.768), Natural Plant Height (0.692) and Thousand Seed Weight (0.451), respectively were found main variation contributor. In 2nd component Seed Yield (0.738) and number of pods per Plant (0.060) were chief variations contributor. In the third component, maximum variations were due to Seed Number per Pod (0.527) and Harvest Index (0.415).

The third location (Fig. 4c) consists of three components. In the first component, Forage Yield (0.958), Straw Yield (0.953), Biological Yield (0.929), Natural Plant Height (0.909) and Pod Number of Per Plant (0.114), respectively. In the second component, Seed Yield (0.935), Thousand Seed Weight (0.868), Harvest Index (0.555), and Seed Number per Pod (0.622) and Dry Matter Yield (0.452) were found.

Analysis of genetic and phenotypic correlations may provide additional benefits to the fundamental analysis of economically important features, as it is used to make indirect choices and predict genetic gain in various annual breeding programs, including soybeans and other annual legumes (Burton, 2011). The cluster analysis of the common vetch inputs tested also confirms that groups may sometimes involve initiatives with close geographical origins, in particular local land areas or varieties used to develop (Potokina et al., 2002).

In this study, biological yield, straw yield, forage yield and natural plant height were included in component 1 at three locations. For this reason, the selection of the genotypes used in the study in the future can be better if the selection is done with these properties. Similar to this study, Mikic et al. (2014) stated that significant differences in the number of common vetch participation and results on the varieties with different geographical origin, feed yield components and related characteristics. Here, information on the relationship between the economically important properties of the 
individual feed yield components, together with the results of the cluster analysis, can help in future reproductive efforts and the selection of parental components for hybridization.

\section{Conclusions}

This study was carried out simultaneously at three (Bilecik, Sivas and Bingol) ecological conditions of Turkey during 2016. It can be concluded that various yield components like biological yield, straw yield, forage yield and natural plant height resulted highly significant variations and can be effectively utilized as selection criteria to start the breeding activities for the common vetch. Average plant height of the genotypes in the locations are between 35.46 and $50.42 \mathrm{~cm}$, the pod numbers of per plant is between 11.51 and 33.01, the seed numbers per pod is between 3.61 and 5.60, the seed yield is between 1487.28 and $1835.14 \mathrm{~kg} \mathrm{da}^{-1}$, the dry matter yield between 325.18 - $560.18 \mathrm{~kg} \mathrm{da}^{-1}$, biological yield between 320.30 and $538.93 \mathrm{~kg} \mathrm{da}^{-1}$, straw yield between 255.27 and $486.84 \mathrm{~kg} \mathrm{da}^{-1}$, seed yield between 76.43 and $106.69 \mathrm{~kg} \mathrm{da}^{-1}$, thousand seed weight between 47.91 and $64.27 \mathrm{gr}$, harvested index was between $27.26 \%$ and $36.43 \%$.

Among the common vetch genotypes in the locations, the highest forage yield and dry matter yield were obtained from the Dicle common vetch genotype, the biological and straw yield were from Kralkizi genotype, and the seed yield was from Ozveren genotype. These results suggested that some previously selected genotypes and superior cultivars can be successfully grown and make a significantly positive contribution. Their introduction into crop-rotation will greatly increase dry matter yield and seed yield and overall sustainability by acting as a disease break and contributing immensely to soil fertility.

Acknowledgements. The authors are thankful to Dr. Ferzat TURAN from Department of Animal Science, Faculty of Agriculture, Ondokuz Mayis University, for making statistical analysis. Authors are also grateful to Bilecik Seyh Edebali University Scientific Research Projects Department for supporting the experiment through Project no: 2015-02. BSEÜ.14-01 at Bilecik location.

\section{REFERENCES}

[1] Acar, Z., Sabanc1, C. O., Tan, M., Sancak, C., Kizilsimsek, M., Bilgili, U., Ayan, I., Karagoz, A., Mut, H., Asci, O. O., Basaran, U., Kir, B., Temel, S., Yavuzer, G. B., Kirbas, R., Pelen, M. A. (2015): Changes in the production of forage crops and new searches. - Turkey Agricultural Engineering VIII. Technical Congress, pp. 508-547.

[2] Acikgoz, E. (2001): Forage Crops. - Uludağ University Strengthening Foundation, No: 182 , Bursa.

[3] Albayrak, S., Töngel, Ö., Güler, M. (2004): Stability analysis and determination of seed yield and yield components of candidate vetch (Vicia sativa $\mathrm{L}$.) varieties in middle Black Sea Region. - Journal of Faculty of Agriculture OMU 20(1): 50-55.

[4] Arystanbekkyzy, M., Nadeem, M. A., Aktas, H., Yeken, M. Z., Zencirci, N., Nawaz, M. A., Ali, F., Haider, M. S., Tunc, K., Chung, G., Baloch, F. S. (2019): Phylogenetic and taxonomic relationship of turkish wild and cultivated emmer (triticum turgidum ssp. dicoccoides) revealed by iPBSretrotransposons markers. International Journal of Agriculture and Biology 21: 155-163. 
[5] Ayasan, T. (2010): The use of bitter vetch (Vicia ervilia L.) in animal feeding. - Journal of Kafkas Veterinary Faculty 16(1): p.167-171.

[6] Burton, J. W. (2011): Quantitative Genetic: Results in Soybean Breeding. - In: Miladinovic, J., Hrustic, M., Vidic, M. (eds.) Soybean. Institute of Field and Vegetable Crops and Soja Protein, Becej, Serbia, pp. 137-183.

[7] Elci, S., Açıkgöz, E. (1993): Guide to Introducing Legumes and Wheat Forage Crops. TİGEM, Avsaroğlu Printing House, Ankara.

[8] Fehr, W. R. (1987): Genotype x Environment Interaction. - In: Fehr, W. R. (ed.) Principles of Cultivar Development. Vol. I.: Theory and Technique. Macmillan Publishing Company, New York, pp. 247-260.

[9] Flores, F., Moreno, M. T., Cubero, J. I. (1998): A Comparison of univariate and multivariate methods to analyze G× E interaction. - Field Crops Research 56: 271-286.

[10] Gauch, H. G., R. W. Zobel. (1996): AMMI Analysis of Yield Trials. - In: Kang, M. S., Gauch, H. G. (eds.) Genotype-by-Environment Interaction. CRC Press, Boca Raton, Florida, pp. 85-122.

[11] Gokkus, A., Koc, A. (1996): Agricultural structure in eastern Anatolia region. - Pastureand Meadow Forage Crops Congress, 17-19 June 1996, Erzurum, pp. 22-31.

[12] Gramsh, E. S. (1982): Variation in the quantitative characters of Vicia sativa L. - Plant Breeding Abs. 52(5).

[13] Gurmani, Z. A., Zahid, M. S. and Bashir, M. (2006): Performance of vetch, Vicia sativa cultivars for fodder production under rainfed conditions of Pothwar region [Pakistan]. Journal of Agricultural Research (Pakistan) 44: 291-297.

[14] Kendal, E., Doğan, Y. (2015): Stability of a candidate and cultivars (Hordeum vulgare L) by GGE biplot analysis of multi-environment yield trial in spring barley. - Agriculture \& Forestry/Poljoprivreda i Sumarstvo 61: 307-318.

[15] Kilic, H., Yagbasanlar, T., Tur, Z. (2003): Genotypic environment interaction of some agricultural properties in durum wheat, stability analysis with heritability estimates. Field Crops Congress of Turkey 1: 52-57.

[16] Kokten, K. (2011): Determination of seed yield and some agricultural characteristics of some common vetch (Vicia sativa L.) lines in Bingol ecological conditions. - Bingol University Journal of Science 2011(1).

[17] Mikic, A., Mihailovic, B., Cupina, D., Milic, D., Katic, S., Karagic, D., Pataki, I., Ottavio, P. D., Kralijevic-Balalic, M. (2014): Forage yield components and classification of common vetch (Vicia sativa L.) cultivars of diverse geographic origin. - Grass and Forage Science 69: 315-322.

[18] Nadeem, M. A., Habyarimana, E., Çiftçi, V., Nawaz, M. A., Karaköy, T., Comertpay, G., Shahid, M. Q., Hatipoğlu, R., Yeken, M. Z., Ali, F., Ercişli, S., Chung, G., Baloch, F. S. (2018): Characterization of genetic diversity in Turkish common bean gene pool using phenotypic and whole-genome DArTseq-generated silico DArT marker information. PloS One 13: e0205363.

[19] Orak, A., Nizam, I. (2004): Agronomic and morphological characters of some common vetch (Vicia sativa L.) genotypes under Trakya Region conditions. - Journal of Agronomy 3: 72-75.

[20] Ozkose, A., Ekiz, H. (2005): Effect of sowing time on yield and yield components in Bitter Vetch (Vicia ervilia (L.) Willd). - Selçuk University Faculty of Agriculture Journal 19: 13-20.

[21] Potokina E., Blattner F. R., Alexandrova T., Bachmann, K. (2002): AFLP diversity in the common vetch (Vicia sativa L.) on the world scale. - Theoretical and Applied Genetics 105: 58-67.

[22] Sabaghnia, N., Dehghani, H., Sabaghpour, S. H. (2006): Nonparametric methods for interpreting genotype $\times$ environment interaction of lentil genotypes. - Crop Science 46: $1100-1106$. 
[23] Sayar M. S., Anlarsal, A. E., Basbag, M. (2013): Genotype-environment interactions and stability analysis for dry-matter yield and seed yield in Hungarian vetch (Vicia pannonica CRANTZ.). - Turkish Journal of Field Crops 18: 238-246.

[24] Seydosoglu, S. (2014): Researches on determination yield and yield components of some common vetch (Vicia sativa L.) genotypes in ecological conditions of Diyarbakır. Turkish Journal of Field Crops 1: 117-127.

[25] Tosun, F. (1974): Leguminous and Cereal Forage Crop Culture. - Atatürk University Faculty of Agriculture Publications, No: 242, Textbook Series No: 8, Erzurum.

[26] TUIK (2013): T. C. Prime Minister Turkey Statistical Institute. http://www.turkstat.gov.tr and crop production statistics (accessed: 02/12/2017).

[27] Unal, S., Firıncioğlu, H. K., Mutlu, Z. (2016): Improvement of winter hardiness in common vetch lines for semi-arid conditions. - Bulgarian Journal of Agricultural Science 22: 756-766.

[28] Yan, W. (2001): GGE Biplot-a windows application for graphical analysis of multienvironment trial data and other types of two-way data. - Agron. J. 93: 1111-1118.

[29] Yucel, C., Gultekin, R., Inal, I., Avci, M. (2008): Determination of yield and yield characters of some common vetch (Vicia sativa L.) lines in Çukurova conditions. Anadolu J. of AARI 18: 38-54. 